\title{
The Role of Sechium edule Fruits Ethanolic Extract in Insulin Production and Malondialdehyde Level in Stz- Induced Diabetic Rat
}

\author{
Betty Lukiati ${ }^{1 *}$, Nugrahaningsih ${ }^{1}$, Siti Nur Arifah ${ }^{2}$ \\ 1) Department of Biology, Faculty of Mathematics and Science, Universitas Negeri Malang \\ 2) Graduate Program of Biology, Department of Biology, Faculty Mathematics and Science, Universitas Negeri Malang \\ *Corresponding author, email: betty.lukiati.fmipa@um.ac.id
}

Keywords:
insulin
MDA
Sechium edule
ethanolic extract
Article history:
Submitted 14/03/2018
Revised 18/02/2019
Accepted 19/02/2019

Keywords:

MDA

Sechium edule

Article history:

Submitted 14/03/2018

Accepted 19/02/2019

\begin{abstract}
The objectives of this research were to examine the effect of Sechium edule ethanolic extract in insulin and Malondialdehyde (MDA) levels in streptozotocin (STZ) induced diabetic rats. Type 1 diabetic rat were obtained by intraperitonially injected with multiple low dose STZ (MLD-STZ) $20 \mathrm{mg} / \mathrm{kgBW}$ for 5 days. The animals were divided into 5 groups: untreated rats in group $(K)$ were considered as negative control, MLD-STZ induced type 1 diabetic rats in group (S) were considered as positive control. In another 3 group $(\mathrm{A}, \mathrm{B}, \mathrm{C})$ type 1 diabetic rats were orally treated with three doses of $S$. edule ethanolic extract $(14,28,42 \mathrm{mg} / \mathrm{kg} \mathrm{BW})$ for 7 days. The animals were sacrificed in two days after last treatment, serum were collected for measuring of the insulin concentration by ELISA method. Level of MDA on kidney, liver and pancreas were measured by TBA method. The treatment with $S$. edule ethanolic extracts unable to increase of insulin yet but the treatment with $42 \mathrm{mg} / \mathrm{kg} \mathrm{BW}$ of $S$. edule ethanolic extract showed significantly decreased MDA levels on liver but not significant on kidney and pancreas.
\end{abstract}

\section{INTRODUCTION}

Sechium edule is a plant that belongs to the family of Cucurbitaceae. The morphological characteristics of $S$. edule are herbaceous, perennial, creeper or climbing plant, and the fruits are fleshly-fibrous (Firdous et al, 2012). S. edule is one of the plants that endemic in Mexico and originally from southern Mexico. Mexican indigenous community used $S$. edule for treating various symptoms such as severe headache, nervousness, and anxiety (Lombardo-Earl et al, 2014). In Indonesia, S. edule fruits usually used as vegetable in many kinds of food. Nahdi et al (2016) reported that Turgo community whose lived in Yogyakarta Province, Indonesia used S. edule as medicinal plants to treat high blood pressure. Based on statistical data in horticulture fields, total production of S. edule in Indonesia were 357.552 at 2014 (Ministry of Agriculture Republic of Indonesia, 2015) and it considered that Indonesian research can develop alternative drugs from active compound in S. edule.
In pharmacological research, $S$. edule were reported as a treatment for various disease such as cardiovascular disease, diabetes mellitus, hypertension, anti-inflammatory, anti-cancer, diuretic, etc (Ordonez et al, 2006). S. edule contains active compound from secondary metabolites such as flavonoid, tannins, carotenoid, saponins, triterpenes, and alkaloids (Salazar-Aguilar et al, 2017). The active compounds from $S$. edule have antioxidant activity as scavenger receptor for free radicals (Albarracin et al, 2010; Fidrianny et al, 2015). $S$. edule reported has antioxidant activity as antiproliferative in human cancer HeLa cell line (Salazar-Aguilar et al, 2017). Mumtaz et al (2013) also reported that treatment using aqueous extract from $S$. edule in streptozotocin-induced diabetic nephropathy rat ameliorates the renal tubules architecture (almost intact tubules and glomeruli).

Type 1 Diabetes Mellitus (T1DM) is one type of DM that many children and adolescents suffer. T1DM caused by pancreas has low production of 
insulin or does not produce any insulin at all. Type 1 diabetes begins with the inflammation of pancreatic beta cell that occurs due to mononuclear cell infiltration (macrophages, lymphocytes and monocytes), followed by the death of beta cell due to the phagocytosis process by macrophages (Suryohudoyo, 2000). Streptozotocin (STZ) is chemical compound which has ability to destroying pancreatic $\beta$ cells. STZ can induced the formation of free radicals such as Nitric Oxide (NO) and reactive Oxygen Species (ROS). STZ decreased oxygen consumption by inhibits the krebs cycle in mitochondria and caused pancreatic $\beta$ cells damage. In other hand, STZ also can caused increasing of Xanthine oxidase which catalysed the formation of superoxide anion. (Siahaan, 2017)

ROS can oxidize polyunsaturated fatty acids (PUFAs) of plasma membranes to form malondialdehyde (MDA) compounds (Ayala et al, 2014) which can altered membrane fluidity, increase permeability, cause the loss of membrane integrity, consequently it will decrease the cell viability (Jaggi and Adav, 2015). The increased level of MDA caused of lipid peroxidation is a pathogenesis symptom which has important role for some diseases, such as DM (Suryawanshi et al, 2006). The treatment for T1DM generally uses insulin. The treatment using insulin injections cannot repair the damage of the pancreatic beta cells, but it only adds insulin exogenously, thereby causing the person to be insulin dependence throughout his life. There have been many researches on the utilization of medicinal plants as an alternative for chemical drugs for the therapy of DM disease. One of the medicinal plants is the S. edule.

The previous research showed that the ethanol extract of $S$. edule can reduce blood glucose levels in Streptozotocin (STZ)-induced DM Wistar rat (Lukiati and Maslikhah, 2014). The ethanol extract of the $S$. edule fruits also could repair $\beta$ cells pancreatic damage and decreased the pancreas NO level in DM wistar rat (Lukiati et al, 2016). This research is a follow-up research with the aim of testing the potential of ethanol extract of $S$. edule to decrease the level of malondialdehyde (MDA) in pancreas, liver and kidney, and increased insulin level of blood serum of DM wistar rats of the induction of streptozotocin (STZ).

\section{MATERIALS AND METHODS}

\section{S. edule Ethanolic Extraction}

Fifty kilograms of $S$. edule fruits were obtained from Materia Medica Batu, then were dried into powder. Nine hundreds gram $S$. edule powder then pass through ethanolic extraction. The extraction of $S$. edule was carried out by repeated maceration method of the $S$. edule powder simplicia using 95\% ethanol solvent. The maceration was done for 3 times until the extract in transparent colour. First maceration was done for $3 \times 24$ hours, the second was $1 \times 24$ hours, and the third was $1 \times 24$ hours. The liquid extract was concentrated with a rotary evaporator at room temperature (Lee et al, 2007) and final result was $400 \mathrm{mg}$ of pasta $S$. edule extract.

\section{STZ Induced Diabetic Rats and Experimental Design}

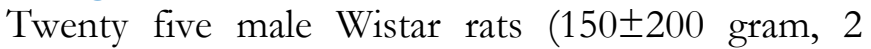
months old) were obtained from CV. Karunia Jasa Pratama, Malang. The animals were housed in standard cage and given free access for food and water. The animals were acclimatized for 7 days. The animals were divided into five groups i.e:

1) $K=$ healthy rats group as the control

2) $\mathrm{S}=\mathrm{STZ}$-induced DM rats not treated with $S$. edule ethanolic extract

3) $\mathrm{A}=\mathrm{STZ}$-induced $\mathrm{DM}$ rats + S. edule ethanolic extract $14 \mathrm{mg} / \mathrm{kgBW}$

4) $\mathrm{B}=\mathrm{STZ}$-induced $\mathrm{DM}$ rats + S. edule ethanolic extract $28 \mathrm{mg} / \mathrm{kgBW}$

5) $\mathrm{C}=\mathrm{STZ}$-induced $\mathrm{DM}$ rats + S. edule ethanolic extract $42 \mathrm{mg} / \mathrm{kgBW}$

The doses of the extract used was calculated based on the simplicia use of human, which is $5-7$ grams, and converted to rats $=\times 0.018$ (weight of the rats wistar strain is 200 gram) (Studiawan and Santosa, 2005). Three different doses of the extract were used in this research based on previous research (Lukiati and Maslikhah, 2014).

After acclimatized, at $8^{\text {th }}$ day, the DM rats were obtained by injecting MLD-STZ (dose $20 \mathrm{mg}$ / $\mathrm{kgBW}$ ) intraperitonialy (ip) for 5 days respectively (Aulanni'am et al, 2005), then the rats were incubated for 14 days. DM rats were determined by blood glucose level when it more than $200 \mathrm{mg} / \mathrm{dL}$ (Hussain, 2002). After in DM state, the animal treated with $S$. edule extract at $23^{\text {rd }}$ day for 7 days. At $32^{\text {nd }}$ day, the blood glucose was observed and the animal were sacrificed. The serum were collected and pancreas, liver, and kidney were removed to observed the MDA level. This research was approved by Institutional Ethic Committee of Brawijaya University (No: 61-KEP-UB).

\section{Measurement of Insulin Level}

The serum which collected at $32^{\text {nd }}$ day were used to observe insulin level. Measurement of insulin leveln accordance with the protocol on Insulin ELISA Rat KIT. Creating a standard curve of insulin with a concentration of $0.15 ; 0.30 ; 0.60 ; 1.25 ; 2.5 ; 5.0 ; 10$ $\mathrm{ng} / \mathrm{ml}$ measured at a wavelength of $450 \mathrm{~nm}$ and 630 
nm. The serum was added with the standard solution incubated for 30 minutes and then the absorbance was measured. The results were then plotted on the standard curve which had already been made to determine the insulin level (Sarode et al, 2016).

\section{Measurement of MDA Level}

The pancreas, liver, and kidney which collected at $32^{\text {nd }}$ day were used to MDA level analysis. The analysis of MDA level used Thiobarbituric acid (TBA) method (Ghanbari et al, 2016). The standard curve for MDA level measurement was in accordance with the protocol of KIT Rat anti MDA polyclonal antibody. Each sample (kidney, liver, pancreas) of 1.8 grams was cut into small pieces and crushed in cold mortar, added $1 \mathrm{~mL}$ of $\mathrm{NaCl} 0.9 \%$, then the homogenate was moved into a micro tube and centrifuged at $8000 \mathrm{rpm}$ for $20 \mathrm{~min}$ and supernatant was taken. Each supernatant of $100 \mu \mathrm{L}$ was added with $550 \mu \mathrm{l}$ aquades, $100 \mu \mathrm{L}$ TCA, 250 $\mu \mathrm{L} \mathrm{HCl} 1 \mathrm{~N}$, and $100 \mu \mathrm{L} \mathrm{Na-Thio,} \mathrm{the} \mathrm{solution} \mathrm{was}$ homogenized, and then centrifuged at $500 \mathrm{rpm}$ for $10 \mathrm{~min}$. The supernatant was taken and incubated in a water bath, $100^{\circ} \mathrm{C}$ in temperatures for 30 minutes. The absorbance of the sample was measured at maximum wavelength for the TBA test $(533 \mathrm{~nm})$ and plotted on the standard curve that had been made to calculate the sample level.

\section{Statistical Analysis}

Statistical analysis of measurement results in insulin and MDA levels using one-way ANOVA and LSD post hoc test, $P$ value $<0.05$ indicated significantly different.

\section{RESULTS AND DISCUSSION}

The research results of the potential Sechium edule ethanolic extract on the insulin level in serum of DM rats are presented in Figure 1.

Based on statistical analysis, the insulin level in serum between groups were not significantly difference. The average of insulin level in $\mathrm{K}$ group was $1127,3 \mathrm{ng} / \mathrm{mL}$, in $\mathrm{S}$ group was $1479,5 \mathrm{ng} / \mathrm{mL}$, in A group was $1131,8 \mathrm{ng} / \mathrm{mL}$, in B group 1054,5 $\mathrm{ng} / \mathrm{mL}$, and in $C$ group was $1181,8 \mathrm{ng} / \mathrm{ml}$. Patil and Kothavade (2018) reported that the serum insulin level in diabetic rat which treated with $0.9 \% \mathrm{NaCl}$ (vehicle group) was $32.65 \mathrm{ng} / \mathrm{mL}$. Based on data showed that treatment using $S$. edule ethanolic extract for 7 days still unable to increase insulin level yet. Another research administration using mango (Mangifera indica) peel ethanol extract for 60 days at doses $100 \mathrm{mg} / \mathrm{kgBW}$ can increase insulin level significantly in T1DM rat compared with untreated/ diabetic group (Gondi and Rao, 2015). Antioxidant effect from Aloe barbadensis gel and skin ethanolic extract also showed increased insulin level until 20\% on 28 days treatment compared with diabetic control rats group (Moniruzzaman et al, 2012). Hemmati et al (2016) reported that the level of insulin after treatment using Berberis vulgaris fruits ethanolic extract on STZ-induced diabetic rats were significantly increased compared with diabetic control rats group. Ethanol extract of Berberis vulgaris that has similar result with glibenclamide as a common drug for DM disease was higher than 100 $\mathrm{mg} / \mathrm{kgBW}$. These reports indicated that the reason $S$. edule ethanolic extract still unable to increase insulin level caused by the administration were done in 7 days only and also low doses of $S$. edule ethanolic extract.

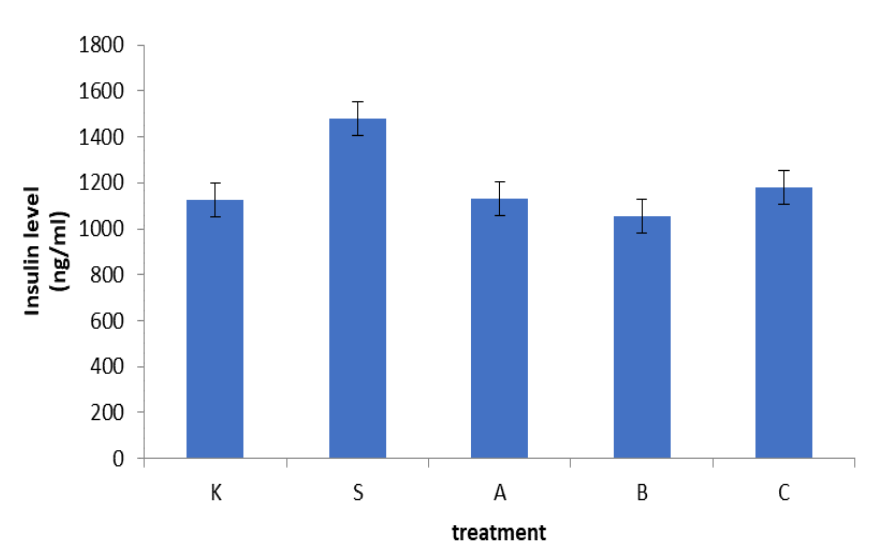

Figure 1. Potential of $S$. edule ethanolic extract on the levels of insulin in the blood serum of DM rats. K, DM rats. K, normal rats. A: DM rats $+S$. edule ethanolic extract dose $14 \mathrm{mg} / \mathrm{kgBW}$. $\mathrm{B}: \mathrm{DM}$ rats + S. edule ethanolic extract dose $28 \mathrm{mg} / \mathrm{kgBW}$. C: $\mathrm{DM}$ rats $+S$. edule ethanolic extract dose $42 \mathrm{mg} / \mathrm{kgBW}$

The potential of $S$. edule ethanolic extract results on the MDA level in the liver, kidney, and pancreas of DM rats are presented in Figure 2.

Based on statistical analysis, the MDA levels in liver were significantly different, meanwhile the MDA levels in the kidney and pancreas were not significantly difference. The MDA level liver, kidney, and pancreas of DM rats is quite high at $2400 \mathrm{ng} /$ $\mathrm{mL}, 1900 \mathrm{ng} / \mathrm{mL}$ and $1942 \mathrm{ng} / \mathrm{mL}$. Anjani et al. (2018) reported that the average of MDA level in the liver of streptozotocin-induced diabetes rats was $227.25 \pm 3.07 \mathrm{ng} / \mathrm{mL}$ while the average of MDA level in normal rats were $148.00 \pm 2.22 \mathrm{ng} / \mathrm{mL}$. After giving treatment with Sechium edule ethanolic extract, the MDA levels in each organ has change. The results showed that Sechium edule ethanolic extract can reduce the MDA levels in the liver of DM rats significantly, but not significantly in the kidney and pancreas. The results of LSD test showed that a dose of $42 \mathrm{mg} / \mathrm{kgBW}$ was an effective dose to reduce MDA levels in liver. Gondi and Rao (2015) 
reported that mango ( $M$. indica) peel ethanol extract also decreased MDA level significantly in T1DM rat model compared with untreated group Treatment using B. vulgaris fruits ethanol extract in low doses (25 mg/kgBW) also showed decreased MDA level significantly compared with diabetic control group (Hemmati et al, 2016). Treatment using A. barbadensis gel and skin ethanolic extract in streptozotocininduced T2DM rats significantly decreased level of MDA compared with diabetic control group (Moniruzzaman et al, 2012).

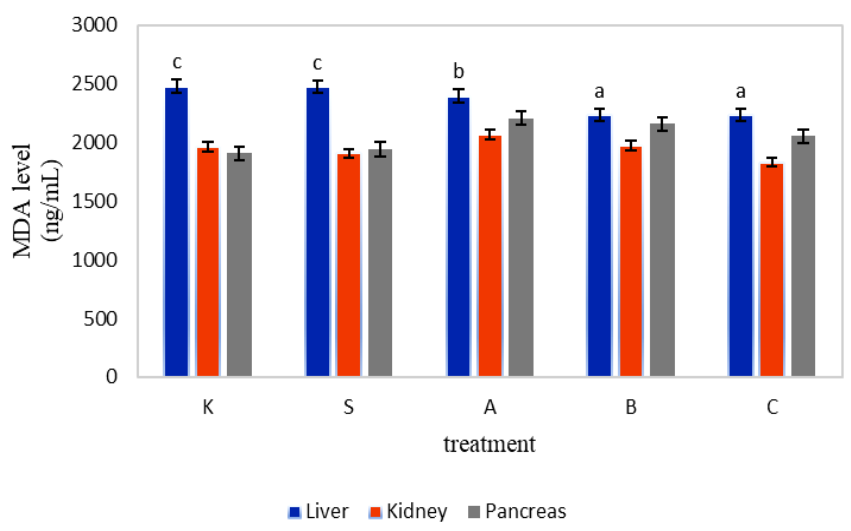

Figure 2. Potential of $S$. edule extract on the MDA level in the liver, kidney, and pancreas of DM rats. $\mathrm{K}$, normal rats. S, DM rats. A, DM rats $+S$. edule ethanolic extract dose $14 \mathrm{mg} / \mathrm{kgBW}$. $\mathrm{B}$, DM rats $+S$. edule ethanolic extract dose $28 \mathrm{mg} / \mathrm{kgBW}$. C, $\mathrm{DM}$ rats $+S$. edule ethanolic extract dose $42 \mathrm{mg} / \mathrm{kgBW}$. Blue colour as liver, orange colour as kidney, grey colour as pancreas. ${ }^{a, b}$ significance different $(P<0.05)$

STZ as an exogenous NO donor can increase some reactive oxygen species (ROS), such as superoxide radicals $\left(\mathrm{O}_{2^{\bullet}}\right)$, hydroxyl radicals $\left(\mathrm{OH}^{\bullet}-\right)$, and hydrogen peroxide $\left(\mathrm{H}_{2} \mathrm{O}_{2}\right)$ (Szkuldelski, 2001), causing methylation DNA of Langerhans beta cell thus causing cell damage (Akinola et al, 2013). Increased ROS causes oxidative stress of the STZinduced rats, resulting in increased levels of MDA in the liver, kidney, or pancreas organ. S. edule ethanolic extract can reduce levels of MDA in DM rats, especially in the kidneys. $S$. edule ethanolic extract can reduced the levels of MDA because it contains flavonoid as active compounds and has antioxidant activity (Aini et al, 2014). The S. edule ethanolic extract was proven to reduce inducible nitric oxide (iNOS) in DM rats (Lukiati et al, 2016). iNOS is an enzyme which plays role in NO generation. NO is a reactive nitrogen species (RNS) group that has similar function as well as ROS. Both of RNS and ROS were free radicals which can mediate for several metabolic degenerative included diabetes mellitus (Soskic et al, 2011).

Antioxidants are compounds that can donate their electrons, in general antioxidants biologically function as an oxidant scavenger and free radicals
(Dauani et al, 2013; Sharma et al, 2013). The action of the antioxidant not only depends on the dose and duration of use but also it is influenced by the type of antioxidant and its environment (Amri et al, 2016). Flavonoid compounds have many double bonds on aromatic rings, so it is a very effective antioxidant compound (Vermerris and Nicholson, 2006). The chemical structure of flavonoid compounds as antioxidants was caused by the presence of: (a). hydroxyl group 3 ', 4' (ortho -dihydroxy) in the B ring flavonoids, (b). 2.3 double bonds conjugated with the 4-oxo group (1.4-piron group) on the $\mathrm{C}$ ring and (c). hydroxyl groups at positions 3 and 5 (Zhang, 2005). Rasyid et al. (2012) reported that chocolate bean extract contained flavonoid can reduce MDA level in order to prevent myocyte damage. Another research reported that administration with licorice flavonoid supplement for 14 days can decrease MDA concentration in serum of obese dogs Kawasumi et al, 2014). Flavonoid were contained S. edule ethanolic extract has ability to decrease MDA level in DM rats and as a result it can reduce free radicals in the body.

The low levels of insulin in rats exposed to STZ are due to the STZ toxic effect that damages the insulin receptor accompanied by the damage of pancreas beta cells (Akinola et al, 2013), so that the glucose entering the pancreas beta cells cannot be responded by insulin receptors. The damage of insulin receptors and pancreas beta cells causes the blood glucose cannot be absorbed into the cells to be used and converted into energy, resulting in high levels of glucose in the blood. The S. edule ethanolic extract was proven to successfully repair the damage of pancreas beta cells as insulin-producing glands (Lukiati et al, 2016). This research shows that the treatment of $S$. edule ethanolic extract up to a dose of $42 \mathrm{mg} / \mathrm{kgBW}$ for 7 days was able to increase insulin production of DM rats, but the increase is not statistically significant. The treatment of the extracts probably requires more than 7 days in order to significantly increase the insulin production.

\section{CONCLUSION}

The decreasing of free radicals resulting on improve metabolism in DM rats. $S$. edule had been able to decrease MDA level in liver. Meanwhile, S.edule ethanolic extract still can not decrease the MDA level in kidney and pancreas. The treatment using $S$. edule ethanolic extract for 7 days with those doses unable able to increase the insulin production in DM rats. Furthermore, the research should be continued with higher doses of $S$. edule ethanolic extract to determine the effective doses for DM treatment. 


\section{ACKNOWLEDGMENT}

The research team expresses their gratitude to the Director General of Higher Education and Institute for Research and Community Service of Universitas Negeri Malang who has assisted in financing this research.

\section{REFERENCES}

Akinola B. O, Zatta L., Dosumu. O. , Akinola S.O., Adelaja A.A, Luciana D.,Ezekiel A., Martin. C., 2013, Intestinal Lesions Of Streptozotocin-Induced Diabetes And The Effect Of Aradirachta indica Treatment, Pharmacologyonline 3, 872-881

Albarracin, G.J., Lopez, R.V.L., Arellano, M.L, Marchesvky, E., and Escudero, N.L. 2010. Bioactive compound and antioxidant capacity of fruit on Sechium edule. Natural Product An Indian Journal 6 (2), 94-101

Aini K., Lukiati B., Balqis, 2014, Skrining Fitokimia Dan Penentuan Aktivitas Antioksidan Serta Kandungan Total Fenol Ekstrak Buah Labu Siam (Sechium edule) [Phytochemical Screening And Determination Of Antioxidant Activity And Total Content of Phenol of chayote Extract (Sechium edule)] Proceeding at Seminar \& Workshop Nasional Biologi/IPA Dan Pembelajarannya, Universitas Negeri Malang, 1004-1009.Amri, A.A.U., Maskoen, A.M., Hidayat, S., 2016, Durian Consumption Effect on Plasma Malondialdehyde Level as Biomarker of Stress Oxidative in Rats, Althea Medical Journal 3(1), 22-28

Anjani, P.P., Damayanthi, E., Rimbawan, and Handharyani, E., 2018, Potential of Okra (Abelmoschus esculentus L.) Etract to Reduce Blood Gucose and Malondialdehyde (MDA) Liver in Streptozotocin-Induced Diabetic Rats, Jurnal Gizi Pangan, 13(1), 47-54

Aulanni'am, Soeatmadji, DW., Fatchiyah, F., dan Sumitro, B.S., 2005, Detection of GAD 65 Auto Antibodies of Type 1 Diabetes Using GAD 65-abs Reagen Produce From Bovine Brain Tissue, Medical Journal of Indonesia, 14, 197-205.

Ayala, A., Munoz, F.M., Arguilles, S., 2014, Lipid Peroxidation: Production, Metabolism, and Signaling Mechanisms Malondialdehyde and 4Hydroxy-2-Nonenal (Rev.), Hindawi Publishing Corporation Oxidative Medicine and Cellular Longevity 2014,1-31

Dauqani, E., Abdullah, A. Sani, H.A., 2013, Lipid Peroxidation In Rat Liver Using Different Vegetable Oils, The Malaysian Journal of Analytical Sciences 17 (2), $300-309$
Fidrianny, I. Ayu, D., and Hartati, R. 2015. Antioxidant capacities, phenolic, flavonoid and carotenoid content of various polarities extracts from three organs of Sechium edule (Jacq.) Swartz. Journal of Chemical and Pharmaceutical Research 7 (5), 914-920

Firdous, S.M., Sravanthi, K., Debnath, R. and Neeraja, K. 2012. Protective effect of ethanolic extract and its ethylacetate and nButanol fractions of Sechium edule fruits against carbon tetrachloride induced hepatic injury in rats. International Journal of Pharmacy and Pharmaceutical Science 4 (1), 354-359

Ghanbari, E., Nejati, V., and Khazaei, M. 2016. Improvement in serum biochemical alterations and oxidative stress of liver and pancreas following use of royal jelly in streptozotocininduced diabetic rats. Cell Journal 18 (3), 362370

Gondi, M. and Rao, U.J.S. 2015. Ethanol extract of mango (Mangifera indica L.) peel inhibits $\alpha$ amylase and $\alpha$-glucosidase activities, and ameliorates diabetes related biochemical parameters in streptozotocin (STZ)-induced diabetic rats. Journal of Food Science and Technology 52 (12), 7883-7893

Hemmawati, M., Serki, E., Gholami, M., and Hoshyar, R. 2016. Effect of an ethanolic extract of Berberis vulgaris fruits on hyperglycemia and related gene expression in streptozotocin-induced diabetic rats. International Journal of Phytomedicine and Phytotherapy 2 (3), 1-7

Hussain, H.E.M., 2002, Revers of Diabetic Retinopathy in Streptozotocin Rats Using Tradisional Indian Ati Diabetic Plant Azadirachta Indika (L), Indian Journal Of Clinical Biochemistry 7, 115-123.

Hussein, H.K. \& Abu-Zinadah, O.A. 2010. Antioxidant effect of Curcumin extracts in induced diabetic Wistar rats. International Journal of Zoology Research 6(4), 266-276

Jaggi, S. \& Yadav, A.S., 2015, Increased serum malondialdehyde levels among cigarette smokers, The Pharma Innovation Journal 4(4), 9496

Kawasumi, K., Okada, Y., Kashiwado, N., Iwazaki, E., Mori, N., Yamamoto, I., and Arai, T. 2014. Effects of administration of Licorice flavonoid supplement on lipid metabolism in obese dogs. Asian Journal of Animal and Veterinary Advances 9(11), 721-726

Lee, Y.L., Weng, C.C., Leun, M.J., 2007, Antioxidant Properties of Ethanolic and Hot Water Extract from The Rhizome of Curcuma aroatica, Journal of Food Biochemistry 31, 757-777. 
Lombardo-Earl, G., Roman-Ramos, R., Zamilpa, A., Herrera-Ruiz, M., Rosas-Salgado, G., Tortoriello, J., and Jimenez-Ferrer, E. 2014. Extract and Fraction from edible roots of Sechium edule (Jacq.) Sw. with antihypertensive activity. Evidence-Based Complementary and Alternatice Medicine 2014, 1-9

Lukiati, B. \& Maslikhah, S.I., 2014, Potensi Ekstrak Etanol Labu Siam (Sechiumvedule) Untuk Terapi Tikus Wistar DM Hasil Induksi Streptozotocin [The potential of Ethanol Extract of chayote (Secbium edule) for the treatment of DM Wistar rats streptozotocin Induced]. Proceeding $1^{\text {st }}$ National Research Symposium. Universitas Negeri Malang, 35-40.

Lukiati, B., Maslikhah, S.I., Nugrahaningsih, 2016. Potensi Ekstrak Etanol Labusiam (Secbium edule) Untuk Perbaikan Kerusakan Sel Beta Pankreas Dan Kadar NO Pada Tikus DM [Potential of chayote Ethanol Extract (Sechium edule) to Repair the damages of Pancreas Beta Cell And NO levels In DM Rats], Jurnal Kedokteran Hewan Universitas Syah Kuala 10 (1), 24-27.

Ministry of Agriculture, Republic of Indonesia. 2015. Statistik Produksi Hortikultura Tahun 2014. Direktorat Jenderal Holtikultura, Kementerian Pertanian, Republik Indonesia.

Moniruzzaman, M., Rokeya, B., Ahmed, S., Bhowmik, A., Khalil, M.I. and Gan,Miller S.H. 2012. In vitro antioxidant effect of Aloe barbadensis Miller extracts and the potential role of these extracts as antidiabetic and antilipidemic agents on streptozotocin-induced type 2 diabetic model rats. Molecules 17, 1285112867

Mumtaz, S.M.F., Paul, S., and Bag, A.K. 2013. Effect of Sechium edule on chemical induced kidney damage in experimental animals. Bangladesh Journal of Pharmacology 8, 28-35

Nahdi, M.S., Martiwi, I.K.A., and Arsyah, D.C. 2016. The ethnobotany of medicinal plants in supporting the family health in Turgor, Yogyakarta, Indonesia. Biodiversitas 17 (2), 900906

Ordonez, A.A.L., Gomez, J.D., Vattuone, M.A, Isla, M.I. 2006. Antioxidant activities of Sechium edule (Jacq) Swartz extracts. Food Chemistry 97 (3), 452-458

Patil, K.P and Kothavade, P. 2018. Comparison of Rosiglitazone and Metformain in Genetically Obese and Diabetic $d b / d b$ Mice and Streptozotocin-Induced Diabetic Rat Model. Biomedical and Pharmacology Journal 11 (1), 325332
Rasyid, H.N., Ismiarto, Y.D., and Prasetia, R. 2012. The efficacy of flavonoid antioxidant from chocolate bean extract: prevention of myocyte damage caused by reperfusion injury in predominantly anaerobic sports. Malaysian Orthopaedic Journal 6(3), 3-6

Salazar-Aguilar, S., Ruiz-Posadas, 1.M., CadenaIniguez, J., Soto-Hernandez, M., SantiagoOsorio, E., Aguniniga-Sanchez, I., RiveraMartinez, A., and Aguirre-Medina, J.F. 2017. Sechium edule (Jacq.) Swartz, a new cultivar with antiproliferative potential in Human Cervical Cancer HeLa cell line. Nutrients 9, 798

Sarode, B.R., Kover, K., Tong, P.Y., Zhang, C., and Friedman, S.H. 2016. Light control of insulin release and blood glucose using an injectable photoactivated depot. Molecular Pharmacentics 13, 3835-3841

Sharma, S.I., Chokshi, S.A., Desai, D., Mewada, H., Signh, A., 2013, Non- Enzymatic Antioxidants, Malondialdehyde, And Antioxidant Activity As Markers Of Oxidative Stress in Arthritis and Rheumatoid Arthritis, NHL Journal of Medical Science 2 (1), 57-60.

Siahaan, J.M. 2017. Effect of antihipoglycemic Sechium edule Jacq. Swartz etanol extract on histopathologic changes in hyperlipidemic Mus musculus L. Journal of Medicine 2 (2), 86-93

Soskic, S.S., Dobutovic, B.D., Sudar, E.M., Obradovic, M.M., Nikolic, D.M. Djordjevic, J.D., Radak, D.J., Mikhailidis, D.P., and Isenovic, E.R. 2011. Regulation of inucible nitric oxide synthase (iNOS) and its potential role in insulin resistance, diabetes and heart failure. The Open Cardiovascular Medicine Journal $5,153-163$

Studiawan, H \& Santosa, M.H., 2005, Uji Aktivitas Penurunan Kadar Glukosa Darah Ekstrak Daun Eugenia polyantha pada Mencit Yang di Induksi Aloksan. Media Kedokteran Hewan 21, 62-65

Suryawanshi NP, Bhutey AK, Nagdeote AN, Jadhav AA, Manoorkar GS., 2006, Study of lipid peroxide and lipid profile in diabetes mellitus, Indian Journal of Clinical Biochemistry 21(1), 126130.

Suryohudoyo.P, 2000, Oksidan, Anti-Oksidan dan Radikal [Oxidants, Anti-Oxidants and Radicals]. KapitaIlmu Kedokteran Molekuler, CV Infomedika, Jakarta

Szkuldelski, T., 2001, Minireview: The Mechanism of Alloxan and Streptozotocin Action in B Cell of The Rat Pancreas. Physiology Research 50, 536-546. 
Udia, P.M., Takem, L.P., Ufot, U.F., Antai, A.B., and Owu, D.U. 2016. Insulin and alpha amylase levels in alloxan-induced diabetic rats and effect of Rothmania hispida (K. Schum) Fagerl leaf extract. The Journal of Phytopharmacology 5 (1), 1-5
Vermerris W \& Nicholson R., 2006, Phenolic Compound Biochemistry, Springer, Netherlands 